\title{
Tiede ja kirjallisuus digimurroksessa
}

Digitalisaatio on vaikuttanut merkittävästi tieteenalojen itseymmärrykseen ja suuntaviivoihin. Digitalisoituminen muuttaa julkaisukulttuureita ja niiden myötä tapojamme ajatella, tuottaa, esittää ja hahmottaa tietoa. Se liittoutuu usein avoimen tieteen eri muotojen, kuten avoimen datan tai avoimen saatavuuden, kanssa. Tieteellisen tiedon ja tietoaineistojen avoimuuteen liitetään arvoja ja ihanteita, kuten tasa-arvo ja vapaus. Keskeisiä periaatteita ovat saatavuus, näkyvyys ja vaikuttavuus. (Berry 2012; Bartling \& Friesike 2014.)

Tieteellisten julkaisukäytänteiden kehittäminen avoimemmaksi aiheuttaa taloudellisia paineita etenkin kotimaisille tiedejulkaisuille, jotka eivät toimi kansainvälisten kustannustalojen ansaintalogiikalla. Julkaisukentän toimintarakenne on muuttumassa, ja kotimaiset lehdet, jotka useimmiten ovat jonkin tieteellisen seuran julkaisemia, joutuvat kamppailemaan eri rahoituslähteiden kanssa ja punnitsemaan omia toimintaedellytyksiään. Kansainvälisellä tasolla tieteellisten seurojen merkitys julkaisutoiminnassa on vähentynyt kaupallistumisen myötä (Lariviére, Haustein \& Mongeon 2015). Suuret kaupalliset toimijat eivät välttämättä aseta julkaisemisessa tieteellisiä arvoja ensisijaisiksi, toisin kuin tieteelliset seurat ja niiden ylläpitämät, usein varsin tiiviiksi muotoutuneet yhteisöt. Tieteellisten seurojen - kuten Kirjallisuuden Tutkijain Seuran tärkeä tehtävä on edelleen digitalisaation aikana taata edellytykset luotettavalle ja vertaisarvioidulle tiedolle.

Hanna-Riikka Roineen ja Laura Piipon toimittama Avaimen teemanumero 2/2021 keskittyi kirjallisuuteen ja sen tutkimukseen digitaalisissa ympäristöissä. Kirjoituksissa nousi esille teknologian, kirjallisuuden ja ihmistoimijuuden monenlainen yhteenkietoutuneisuus nykyaikana. Tässä numerossa Viola Parente-Čapkován katsaus jatkaa keskustelua digitaalisuuden ja kirjallisuuden yhteisestä historiasta tarkentamalla sitä, miten digitaalinen kirjallisuudentutkimus on muuttanut kirjallisuushistoriaa. Katsaus esittelee digitaalisten ihmistieteiden (Digital Humanities) avaamia metodologisia mahdollisuuksia kirjallisuudentutkimuksen kannalta. Tähän liittyy muuan muassa monikielisyyttä ja sukupuolta koskevia eettisiä kysymyksiä, jotka saatetaan "raakaa dataa" korostavassa tutkimuksessa ohittaa kokonaan.

Digitaalisuus voi tarkoittaa digitaalisten ilmiöiden tutkimista kirjallisuudessa, sillä sosiaalinen media on osa nykykirjallisuuden representaatioita. Esimerkiksi Hanna-Riikka Kuisman romaani \#Syyllinen (2021) vyöryttää esiin somen raadollisena oman elämän kulissien rakennus- ja tuhoutumispaikkana, jolla on yhteys yhteiskunnalliseen epäoikeudenmukaisuuteen. Digitalisaation 
ja teknologian synnyttämät muutokset ovat tutkimuskohteina myös kahdessa tämän numeron artikkelissa. Heta Marttisen artikkeli tutkii teknologiavälitteisen vuorovaikutuksen ja epäsosiaalisen viestinnän muotoja henkilöhahmojen dynamiikassa Kaj Korkea-ahon ja Ted Forsströmin nuortenromaanisarjassa Zoo! Marttisen analyysi osoittaa, miten sosiaalinen media ei toimi kirjasarjassa vain vuorovaikutuksen ylläpitämisessä, vaan sillä on keskeinen merkitys henkilöhahmojen ihmissuhteiden muodostamisessa ja määrittelyssä. Myös Hanna Huhtisen artikkeli käsittelee teknologiavälitteistä vuorovaikutusta. Analyysi syventyy Johannes Ekholmin ja Sisko Savonlahden romaaneihin, joissa päähenkilöiden arki kuvataan digiteknologian rytmittämänä. Analyysinsä tukena Huhtinen kehittelee teknologisen tiedostamattoman käsitettä, joka nykyfiktion yhteydessä peilaa teknologian valtaa ja digitaalisen kulttuurin synnyttämiä muutoksia yksilössä.

Myös Marko Pajulan artikkeli käsittelee Sisko Savonlahden huomiota herättänyttä romaania Ehkä tänä kesänä kaikki muuttuu (2018). Pajula tutkii uusliberalistista kulutuskulttuuria ja itsen markkinoinnin keskeisyyttä romaanissa ja ehdottaa, että uusliberaalin subjektin tarkempi paikallistaminen voi antaa paremman ymmärryksen luokan ja muiden taloudellisten rakenteiden merkityksestä sosiaaliselle elämälle. Heidi Hakkarainen tutkii artikkelissaan Viipurissa 1800-luvun alkupuolella ilmestyneiden saksankielisten lehtien roolia kirjallisuuden foorumina. Tarkasti kontekstualisoitujen esimerkkien avulla Hakkarainen havainnollistaa, miten paikalliset kirjalliset kokeilut ja keskustelut olivat vuorovaikutuksessa laajempaan ylirajaiseen tekstien verkostoon ja kirjalliseen elämään saksankielisessä kulttuuripiirissä. Susanna Itäkareen artikkeli pureutuu kristilliseen fundamentalismiin ja toiseuden problematiikkaan Markku Karpion nuortenromaanissa Tie auki taivasta myöten (2001). Itäkare lukee teosta suhteessa muuttuvaan suomalaiseen uskonnollisuuteen ja esittää romaanin ennemminkin uusintavan stereotyyppistä ajattelua uskonyhteisöistä kuin edistävän yhteiskunnallista vuoropuhelua.

Lauri Niskasen lektio James Joycen Ulysseksen suomen- ja ruotsinkielisiin käännöksiin keskittyvästä väitöstutkimuksesta avaa klassikkoteoksen julkaisuhistoriaa sekä suomen- ja ruotsinkielisiin käännöksiin liittyviä vaiheita. Niskanen korostaa uudelleenkäännöksiä kriittisinä ja hermeneuttisina tulkintoina, joissa kääntäjällä on aktiivinen rooli toimijana ja tekijänä. Käännöksiä tuleekin Niskasen mukaan lähestyä luovan yhteistyön ja dialogin tuloksina.

Kirja-arvioissa Jyrki Korpua esittelee Pekka Vartiaisen ajankohtaiseen aiheeseen tarttuvaa teosta Ruttovuosi - Kirjoituksia kaunokirjallisuuden epidemiakuvauksista (2021), joka tarjoaa pandemia-ajan lukijalle esseistisiä näkökulmia länsimaisen kirjallisuuden kanonisoituihin teksteihin. Kaarna Tuomenvirta arvioi Colin Davisin ja Hanna Meretojan toimittamaa järkälemäistä käsikirjaa 
The Routledge Companion to Literature and Trauma (2020), joka sisältää artikkeleita traumatutkimuksen teoreettisista ja filosofisista lähtökohdista, käsitteistä, kritiikistä ja uusista suuntauksista sekä traumaattisten tapahtumien representaatioista.

Riitta Jytilä \& Lotta Kähkönen

\section{Kirjallisuus}

Bartling, Sönke \& Sascha Friesike (eds) 2014. The Evolving Cuide on How the Internet is Changing Research, Collaboration and Scholarly Publishing. Cham: Springer International Publishing, 3-15. DOI: 10.1007/978-3-319-00026-8_1.

Berry, David M. 2012. Introduction: Understanding the Digital Humanities. Teoksessa Understanding Digital Humanities. Ed. David Berry. Basingstoke \& New York: Palgrave Macmillan, 1-20.

Lariviére, Vincent, Stefanie Haustein \& Philippe Mongeon 2015. The Oligopoly of Academic Publishers in the Digital Era. PLOS ONE, 10(6), e0127502-15. DOI: 10.1371/journal.pone.0127502. 